\title{
DINAMIKA SUBAK LUNGATAD DESA PEGUYANGAN TIMUR KOTA DENPASAR
}

\section{Dynamics of Subak Lungatad of East Peguyangan Village, Denpasar}

\author{
Wayan Sudarta \\ Program Studi Agribisnis, Fakultas Pertanian, Universitas Udayana, Bali, Indonesia \\ E-mail: sudarta@gmail.com
}

\begin{abstract}
This study aims to determine the state of the elements and dynamics of Subak Lungatad, Peguyangan Timur Village, Denpasar City. The results showed that in general the state of the Subak Lungatad elements was in good condition, as well as the dynamics of the subak included in the good category. Based on the findings in this study, it can be recommended: (1) the objectives of subak that are too abstract and very long-term need to be avoided, because it is difficult for members to imagine, and (2) a written system of rewards for members who obey norms and achievements.
\end{abstract}

Keywords: Dynamics, Subak Lungatad, achievement

\section{ABSTRAK}

Penelitian ini bertujuan untuk mengetahui keadaan elemen-elemen dan dinamika Subak Lungatad, Desa Peguyangan Timur, Kota Denpasar. Hasil penelitian menunjukkan, bahwa secara umum keadaan elemen-elemen Subak Lungatad dalam keadaan baik, demikian juga dinamika subak tersebut termasuk kategori baik. Berdasarkan temuan dalam penelitian ini dapat direkomendasikan: (1) tujuan subak yang terlampau abstrak dan berjangka sangat panjang perlu dihindari, karena sulit dapat dibayangkan oleh para anggota, dan (2) perlu dirumuskan secara tertulis sistem penghargaan bagi anggota yang taat kepada norma dan berprestasi.

Kata kunci: Dinamika, Subak Lungatad, norma dan berprestasi

\section{PENDAHULUAN}

Setiap subak (kelompok tani tradisional yang bergerak di lahan sawah) mempunyai dinamika. Namun, dinamika subak yang satu bisa berbeda dengan dinamika subak yang lain. Hal itu sangat bergntung pada keadaan elemen-elemen subak yang bersangkutan. Apabila elemen-elemen suatu subak keadaannya baik, maka dinamika subak itu akan baik pula, sebaliknya apabila leemen-elemen subak tersebut keadaannya tidak baik, maka dinamika subak yang bersangkuatan juga tidak baik. Dinyatakan oleh Jenkins (dalam Suyatna, 1982) bahwa dinamika kelompok dapat diartikan sebagai suatu kekuatan-kekuatan di dalam kelompok yang menentukan perilaku kelompok dan perilaku anggota kelompok dalam melaksanakan berbagai kegiatan untuk tercapainya tujuan bersama yang menjadi tujuan kelompok.

Setiap anggota subak selalu menharapkan agar subak tempat dia menjadi anggota efisien dan efektif dalam mencapai tujuan bersama. Termasuk juga dapat memanfaatkan segala potensi yang ada dalam subak dan lingkungannya dalam upaya mncapai tujuan bersama tersebut. Pencapaian tujuan bersama yang menjadi tujuan subak tersebut, harus dapat dirasakan oleh para anggota subak secara individu. Setiap anggota merasa bangga dan berbahagia berasosiasi dalam subak yang bersangkutan.

Dikemukakan oleh Slamet (1978) dan Soedijanto (1980) dinamika kelompok (termasuk subak) tergantung pada sembilan faktor atau elemen, mencakup (1) tujuan kelompok, (2) struktur kelompok, (3) fungsi tugas, (4) pembinaan kelompok, (5) kekompakan/kesatuan kelompok, (6) suasana kelompok, (7) tekanan pada kelompok, (8) efektivitas kelompok, dan (9) maksud-maksud terselubung. Kesembilan faktor atau elemen subak itu harus keadaannya baik, untuk mewujudkan dinamika subak yang baik.

Berdasarkan latar belakang pemikiran tersebut, kiranya menarik untuk dikaji bagaimana keadaan elemen-elemen dan dinamika Subak Lungatad, Kota Denpasar, yang dipilih secara sengaja sebagai lokasi peneitian.

\section{LANDASAN TEORI}

Dinamika subak sebagaimana telah disinggung sebelumnya, dapat dilihat baik berdasarkan W. Sudarta, Dinamika...| 63 
pendekatan psikososial maupun pendekatan sosiologis (sistem sosial), atau kombinasi antara kedua pendekatan itu. Namun pada bagian ini, akan dijelaskan hanya, pendekatan yang digunakan dalam penelitian ini, yakni pendekatan psikososial.

Dijelaskan oleh Slamet (1978) dan Soedijanto (1980) pendekatan psikososial terdiri atas sembilan elemen sebagai berikut.

\section{1) Tujuan Kelompok}

Tujuan kelompok dapat diartikan sebagai segala sesuatu yang ingin dicapai oleh kelompok. Tujuan kelompok perlu dinyatakan secara tertulis, sehingga format adanya. Tujuan kelompok perlu juga dirumuskan secara jelas, dan konkrit (sehingga mudah dibayangkan dan dipahami oleh anggota). Tujuan keolompok harus berorientasi kepada pemenuhan kebutuhan pribadi anggota, sehingga tujuan kelompok searah dengan tujuan pribadi anggota. Artinya, tujuan kelompok atau tujuan bersama tercapai, tujuan pribadi anggota kelompok juga tercapai.

\section{2) Struktur Kelompok}

Elemen struktur organisasi adalah cara kelompok mengatur diri dalam upaya mencapai tujuan bersama. Yang terpenting diperhatikan di sini meliputi (a) struktur kekuasaan (pengambilan keputusan); (b) struktur tugas (pembagian pekerjaan) disesuaikan dengan kedudukan dan peranan; dan (c) struktur komunikasi (aliran-aliran informasi) yang terjadi di dalam kelompok baik dan lancar.

\section{3) Fungsi Tugas}

Fungsi tugas kelompok dapat diartikan sebagai segala sesuatu yang seharusnya dilakukan oleh kelompok, untuk tercapainya tujuan kelompok atau tujuan bersama. Terkait dengan ini, yang perlu diperhatikan sebagai berikut. (a) Anggota selalu mendapatkan informasi baru, dan juga mendapat penjelasan kalau menghadapi situasi yang membingungkan. (b) Anggota merasa puas karena tercapainya tujuan kelompok dan tujuan pribadi anggota; (c) Terciptanyan koordinasi yang baik. (d) Ada motivasi yang tinggi di kalangan anggota dalam bekreativitas dan beraktivitas, dalam upaya mencapai tujuan kelompok.

\section{4) Pembinaan Kelompok}

Pembinaan kelompok dapat didefinisikan sebagai suatu usaha untuk menjaga kehidupan kelompok. Berkaitan dengan pembinaan kelompok, perlu diperhatikan sebagai berikut. (a) Ada kegiatankegiatan yang mengikutsertakan anggota. (b) Tersedianya fasilitas yang dibutuhkan untuk melaksanankan beragam kegiatan itu. (c) Terlaksananya komunikasi dan koordinasi yang baik. (d) Ada kontrol sosial atau pengendalian terhadap perilaku anggota kelompok.

\section{5) Kekompakan atau Kesatuan Kelompok}

Elemen kekompakan atau kesatuan kelompok adalah rasa keterikatan yang kuat di kalangan anggota terhadap kelompok. Hal-hal yang perlu diperhatikan dalam kaitan ini sebagai berikut. (a) Ada rasa memiliki. (b) Anggota kelompok menjamin terwujudnya kekompakan dan kerjasama. (c) Nilai yang melekat pada tujuan dipandang tinggi (luhur, mulia, dan terhormat). (d) Latar belakang anggota mempunyai homogenitas yang tinggi. (e) Integritas (pembauran) anggota yang tinggi.

\section{6) Suasana (atmosfir) Kelompok}

Suasana (atmosfir) kelompok dapat diidentikkan dengan keadaaan moral, sikap dan perasaanperasaan umum yang terdapat dalam kelompok. Faktor-faktor yang mempengaruhi suasana kelompok meliputi sebagai berikut. (a) Hubungan antar anggota (apakah rukun, damai dan kekeluargaan, atau kaku, tegang/ konfrontatif dan formal). (b) Kebebasan anggota berpartisipasi (suasana bebas berkreativitas, atau serba diawasi/dikekang sehingga mematikan kreativitas). (c) Lingkungan fisik yang kondusif, akan membawa kelompok ke dalam suasana yang lebih baik.

\section{7) Tekanan atau Tegangan pada Kelompok}

Elemen tekanan pada kelompok didefinisikan sebagai segala sesuatu yang dapat menimbulkan tekanan/tegangan terhadap kelompok, yang dapat menyebabkan kelompok berusaha secara lebih intensif mencapai tujuan kelompok. Beberapa hal yang perlu diperhatikan dalam kaitan ini sebagai berikut. (a) Adanya tuntutan dan harapan dari anggota. (b) Ada sistem penghargaan dan sistem penghukuman. (c) Ada tuntutan dan harapan dari luar kelompok. Tekanan/tegangan tersebut, perlu dalam kadar yang optimal, sebab tekanan/tegangan yang terlampau tinggi atau rendah berpengaruh buruk bagi dinamika kelompok.

\section{8) Efektivitas Kelompok}

Efektivitas kelompok dapat diartikan sebagai suatu keberhasilan kelompok dalam mencapai tujuan, baik tujuan kelompok maupun tujuan pribadi anggota. Efektivitas kelompok dapat dilihat dari tiga aspek berikut ini. (a) Produktivitas, diukur dari keberhasilan kelompok mencapai tujuan. (b) Moral, dapat dilihat dari semangat dan sikap anggota (mereka merasa bangga dan bahagia berasosiasi dalam kelompok yang bersangkutan). (c) Kepuasan anggota, dapat dilihat dari keberhasilan anggota mencapai tujuan pribadi masing-masing. Tujuan tercapai berarti kebutuhan terpenuhi. Kebutuhan terpenuhi berarti anggota memperoleh kepuasan. Kepuasan tercapai akan memotivasi anggota untuk bergiat dalam mencapai tujuan. Demikian seterusnya, merupakan suatu lingkaran.

\section{9) Maksud-maksud Terselubung pada Kelompok}

Maksud-maksud terselubung pada kelompok, artinya ada anggota yang mempunyai pamrih lain yang tidak dinyatakan secara terbuka. Hal-hal yang perlu diperhatikan berkaitan dengan itu sebagai berikut. (1) Tidak ada anggota yang ambisius. (2) Tidak ada anggota yang ingin meraih keuntungan secara pribadi, sehingga merugikan kelompok. (3) 
Tidak ada anggota sebagai pemecah belah kelompok.

\section{KERANGKA PEMIKIRAN}

Subak sebagai suatu kelompok atau organisasi mempunyai sejumlah elemen. Apabila salah satu elemen keadaannya tidak baik, maka akan dapat mempengaruhi seluruh elemen yang ada, sehingga pencapaian tujuan subak menjadi kurang optimal. Demikian pula sebaliknya, apabila seluruh elemen tersebut keadaannya baik, maka diyakini subak akan mampu mencapai tujuan secara lebih optimal. Berdasarkan pemikiran tersebut, maka tujuan penelitian ini untuk mengetahui kedaan elemenelemen dan dinamika Subak Lungatad, Kota Denpasar.

Untuk melihat keadaan elemen-elemen dan dinamika Subak Lungatad dalam penelitian ini, digunakan alat ukur psikososial, yang memiliki sembilan elemen. Kesembilan elemen itu meliputi (1) tujuan kelompok; (2) struktur kelompok; (3) fungsi tugas kelompok; (4) pembinaan kelompok; (5) kekompakan/kesatuan kelompok; (6) suasana/atmosfir kelompok; (7) tekanan/tegangan kelompok; (8) efektivitas kelompok, dan (9) maksud-maksud terselubung pada kelompok. Setelah data dikumpulkan melalui wawancara mendalam dari informan kunci melalui pedoman wawancara dan melalui Focus Group Discussion
(FGD), data dianalisis secara deskiptif-kualitatif. Melaui metode itu, tujuan penelitian dapat dicapai berupa simpulan. Berdasarkan simpulan dan temuan dalam penelitian ini, dapat diberikan rekomendasi kepada subak yang bersangkutan. Secara sitematis, kerangka pemikiran tersebut tampak pada Gambar 2.1.

\section{METODE PENELITIAN}

\section{Tempat dan Waktu}

Peneitian ini dilakukan di Subak Lungatad, Desa Peguyangan Timur Kota Denpasar. Penetuan lokasi ini dilakukan secara sengaja dengan pertimbangan bahwa Subak Lungatad ditetapkan sebgai jalur hijau oleh Pemerintah Kota Denpasar, yang berarti subak ini potensial untuk dilestarikan, walaupun di tengahtengah alih fungsi lahan yang demikian pesat di Kota Denpasar.

Waktu penyelenggaraan penelitian ini pada pertengahan bulan Mei s.d pertengahan bulan Juni 2017, yakni mulai dari survei pendahuluan sampai dengan analisis data.

\section{Jenis dan Sumber Data}

Jenis data yang digunakan dalam penelitian ini, meliputi data kuantitatif dan kualitatif dengan penjelasan sebagai berikut.

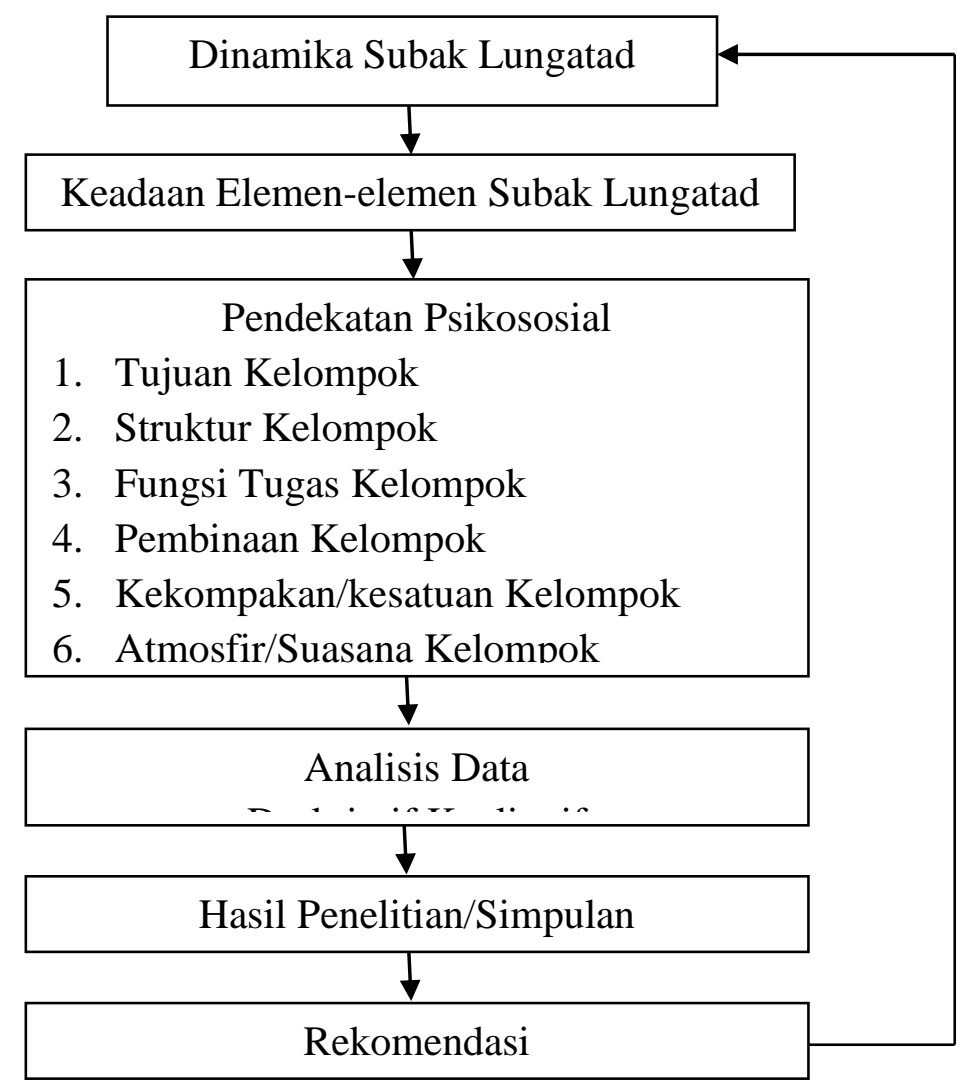

Gambar 1 Kerangka Pemikiran Dinamika Subak Lungatad, Desa Peguyangan Timur, Kota Denpasar Tahun 2017. 
a. Data kuantitatif adalah data yang berupa nagka atau data yang dapat dihitung dan dinyatakan dalam bentuk satuan. Data kuantitatif dalam penelitian ini, diantaranya daftar nama dan jumlah pengurus Subak Lungatad, sebagai calon informan kunci dan peserta.

b. Data kualitatif adalah data yang tidak dapat dihitung dalam bentuk angka, tetapi berupa kata, kalimat, skema dan gambar atau data yang berupa keterangan-keterangan yang berkaitan dengan penelitian. Data kualitatif dalam penelitian ini meliputi, tujuan subak, struktur subak, fungsi tugas, pembinaan kelompok, kekompakan atau kesatuan kelompok, suasana kelompok, tekanan/tegangan kelompok, efektivits kelompok, maksud-maksud terselebung pada kelompok, dan lainnya.

Sumber data yang digunakan dalam penelitian ini mencakup data primer dan data sekunder, dengan penjelasan sebagai di bawah ini.

a. Data primer adalah data yang diperoleh langsung dari sumbernya, diamati dan dicatat pertama kalinya. Data primer dalam penelitian ini bersumber dari informan kunci dan FGD seperti telah disebutkan di atas.

b. Data sekunder adalah data yang diperoleh secara tidak langsung untuk mendapatkan informasi atau dari objek yang diteliti, untuk mendukung data penelitian. Umpama saja data yang bersumber dari buku-buku, dan catatan yang terdokumentasi di Subak Lungatad.

\section{Penentuan Informan Kunci dan Peserta Diskusi}

Sebagai informan kunci dalam penelitian ini hanya ada dua orang, yakni Pekaseh dan Sekretaris (Penyarikan) Subak Lungatad. Kemudian, peserta diskusi dari Subak Lungatad sebanyak 12 orang, terdiri atas Pekaseh, Penyarikan, dan para tokoh Subak Lungatad yang ditentukan secara sengaja dengan kriteria yang bersangkutan dipandang mampu menjelaskan atau memberikan informasi berkitan dengan tujuan penelitian ini. Peserta diskusi itu, ditentukan oleh Pekaseh Subak Lungatad dengan kriteria seperti tersebut.

\section{Pengumpulan Data}

Pengumpulan data dalam penelitian ini dilakukan sebagai berikut.

1. Melalui wawancara mendalam kepada Pekaseh (pemimpin subak) dan Sekretaris Subak Lungatad dengan instrumen pedoman wawancara.

2. Focus Group Disscusion (FGD) antara peneliti dibantu oleh para mahasiswa dengan para petani (pengurus dan para tokoh anggota subak). FGD adalah diskusi yang dilakukan secara sistematis, terarah dan terfokus tentang masalah tertentu yang spesifik melalui diskusi kelompok (Bungin,2013). Ini dilakukan diskusi antara peneliti dan para mahasiswa dengan pengurus dan para tokoh petani anggota Subak
Lungatad tersebut, mengenai keadaan elemenelemen Subak Lungatad. Dengan demikian terjadi dialog secara terbuka. Untuk mengetahui keadaan elemen-elemen Subak Lungatad digunakan alat ukur pendekatan psikososial seperti telah diuaraikan sebelumnya.

\section{Analisis Data}

Analisis data merupakan proses mencari dan menyusun secara sistematis data yang diperoleh dari hasil wawancara mendalam, catatan lapangan dan dokumentasi. Proses analisis data dilakukan dengan menelaah data yang ada berasal dari berbagai sumber (Sugiyono, 2017).

Analisis data dalam penelitian ini dilakukan secara deskriptif-kualitatif adalah analisis yang menggambarkan secara sistematis fakta dari karakteristik objek atau subjek yang diteliti secara tepat dan apa adanya. Data dalam penelitian ini bersumber dari wawancara mendalam, FGD, dan dokumentasi.

\section{HASIL DAN PEMBAHASAN}

\section{Keadaan Elemen-elemen Subak Lungatad}

Mengkaji dinamika Subak Lungatad berari mengkaji semua elemen dan semua indikator pada setiap elemen subak tersebut. Ini artinya, sebelum dibahas mengenai dinamika Subak Lungatad terlebih dahuliu perlu dibahas mengenai keadaan semua indikator pada setiap elemen subak yang bersangkutan. Adapun keadaan elemen-elemen Subak Lungatad, tertuang pada Tabel 1.

Data yang tertuang pada Tabel 1 memberikan pemahaman sebagai di bawah ini.

(1) Ada dua indikator $(6,1 \%)$ saja, dari 33 indikator yang terdapat pada Sembilan elemen Subak Lungatad, yang keadaannya tidak baik. Selebihnya, yakni 31 indikator (93,9\%) keadaannya termasuk baik.

(2) Kedua indikator yang keadaannya tidak baik itu, terdapat pada elemen tujuan subak dan tekanan atau tegangan pada subak. Seharunya, tujuan subak dirumuskan secara jelas dan konkrit (lebih bersifat jangka pendek dan menengah), sehingga mudah dapat dibayangkan oleh para anggota subak. Dengan demikian, hal ini akan dapat memotivasi para anggota untuk berkreativitas dan beraktivitas untuk mencapai tujuan subak. Tujuan subak yang dirumuskan dalam Subak Lungatad, kenyataannya lebih bersifat jangka panjang dan abstrak sehingga sulit dapat dibayangkan oleh para anggota. Keadaan ini tidak dapat memotivasi para anggota untuk berinisiatif dan bergiat dalam mencapai tujuan subak yang merupakan tujuan bersama. Kemudian pada elemen tekanan atau tegangan subak, seharusnya ada sistem penghargaan tertulis bagi anggota yang menaati norma (awig-awig 
atau perarem subak) dan berprestai. Tetapi kenyataannya, hal ini belum ada di Subak Lungatad.
(3) Berdasarkan telaahan tersebut, dapat dikatakan bahwa umumnya elemen-elemen Subak Lungatad termasuk baik.

Tabel 1. Keadaan Indikator-indikator pada Setiap Eleme $\sqrt{ } n$ Subak Lungatad, Desa Peguyangan Timur, Kota Denpasar, Tahun 2017.

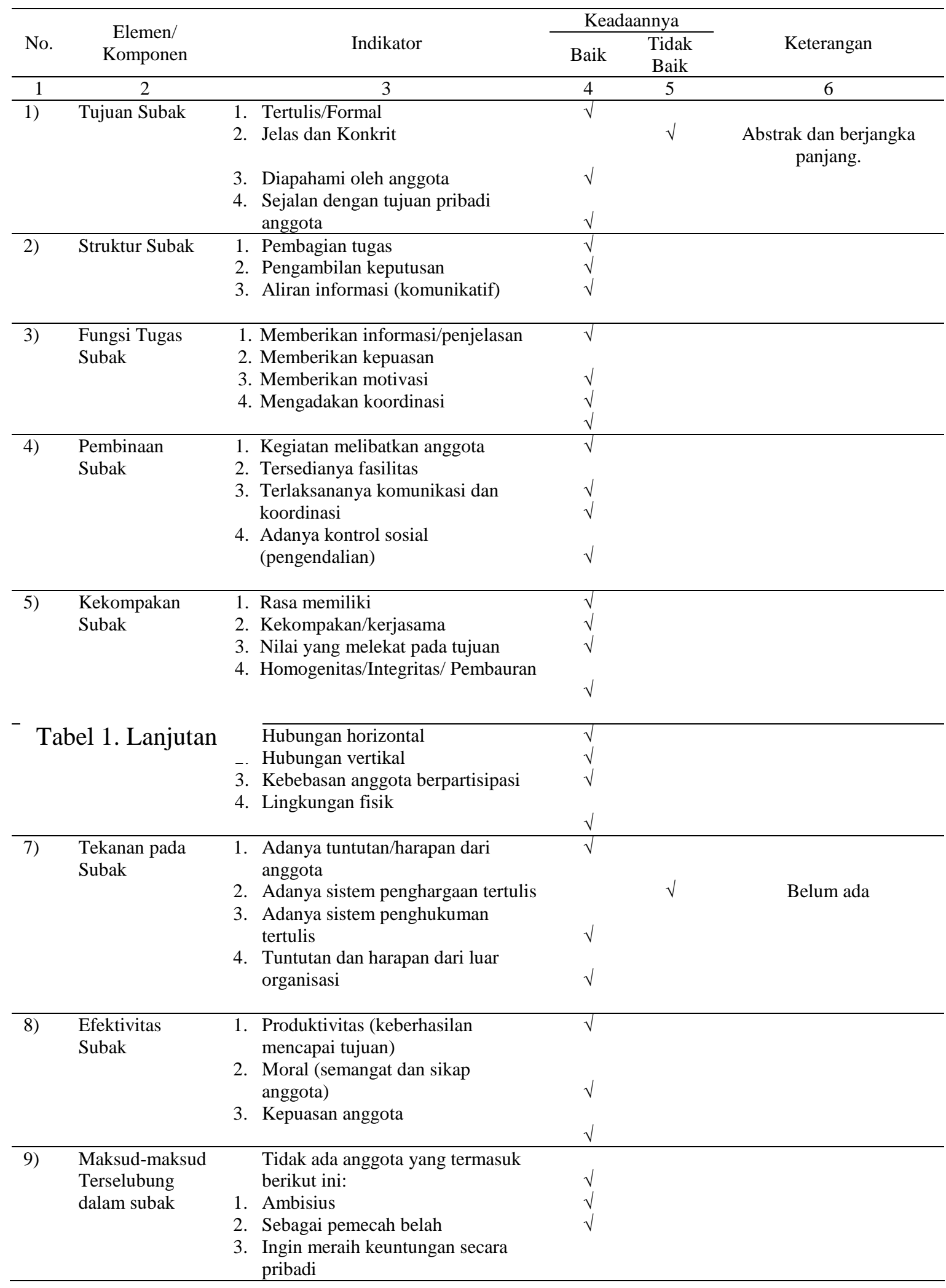




\section{Dinamika Subak}

Bersumber dari data yang tersaji pada Tabel 1, dapat digambarkan dinamika Subak Lungatad seperti tampak pada Tabel 2, dengan catatan sebagai berikut.

(1) Elemen subak yang terdiri atas tiga indikator; dinamika subak termasuk "baik" apabila tiga indikator keadaannya baik; termasuk "sedang" apabila dua indikator keadaannya baik; dan termasuk "tidak baik" apabila hanya satu indikator keadaannya baik, atau tidak ada indikator yang keadaannya baik.

(2) Elemen subak yang terdiri atas empat indikator; dinamika subak termasuk "baik" apabila empat indikator keadaannya baik; termasuk "sedang" apabila dua atau tiga indikator keadaannya baik; dan termasuk "tidak baik" apabila hanya satu indikator keadaannya baik, atau semua indikator keadaannya tidak baik.

Data yang tersaji pada Tabel 2 menunjukkan, bahwa sebagian besar $(77,8 \%)$ elemen subak dinamikanya termasuk baik, dan sebagian kecil $(22,2 \%)$ elemen subak termasuk sedang. Malahan tidak ada elemen Subak Lungatad yang dinamikanya termasuk tidak baik. Berdasarkan fakta tersebut, dapat dikatakan bahwa dinamika Subak Lungatad termasuk baik.

Tabel 2. Dinamika Subak Lungatad, Desa Peguyangan Timur, Kota Denpasar, Tahun 2017.

\begin{tabular}{llcc}
\hline \multirow{2}{*}{ No } & \multicolumn{1}{c}{ Elemen Subak } & \multicolumn{2}{c}{ Dinamika Subak } \\
\cline { 3 - 3 } 1. & Tujuan Subak & Baik & Sedang \\
2. & Struktur Subak & $\sqrt{ }$ \\
3. & Fungsi Tugas Subak & $\sqrt{ }$ \\
4. & Pembinaan Subak & $\sqrt{ }$ \\
5. & Kekompakan Subak & $\sqrt{ }$ \\
6. & Suasana/ Atmosfir Subak & \\
7. & Tekanan pada Subak & $\sqrt{ }$ \\
8. & Efektivitas Subak & $\sqrt{ }$ \\
9. & Maksud-maksud Terselubung pada Subak & \\
\hline
\end{tabular}

\section{KESIMPULAN}

Berdasarkan hasil kajian seperti telah dibahas tersebut, dapat dismpulkan bahwa dinamika Subak Lungatad termasuk "baik". Mengacu pada temuan yang didapatkan dalam penelitian ini, ada dua hal yang perlu diperhatikan oleh Subak Lungatad, sebagai berikut. (1) Perumusan tujuan subak, jangan terlalu umum, bersifat abstrak dan jangka pangjang, tetapi sebaiknya lebih ditonjolkan perumusan tujuan subak yang spesifik, bersifat konkrit, berjangka pendek dan menengah, sehingga mudah dibayangkan oleh para anggota. (2) Perlu ada sistem penghargaan tertulis dalam subak, sehingga ada motivasi untuk maju bagi yang taat pada norma dan berprestasi.

\section{DAFTAR PUSTAKA}

Bungin, Burhan. 2003. Analisis Data Penleitian Kualitatif. PT. Raja Grafindo Persada Jakarta.

Slamet, Margono. 1978. Beberapa Catatan tentang Pengembangan Organisasi. Dalam
Margono Slamet (Ed). 1978. Penyuluhan Pertanian. Edisis Ketiga. IPB Bogor.

Soedijanto. 1980. Organisasi, Kelompok dan Kepemimpinan. IPLPP. Ciawi Bogor.

Sudarta, Wayan. 2004. Kelompok, Organisasi dan Kepemimpinan Jurusan Sosial Ekonomi Pertanian, Fakultas Pertanian Universitas Udayana. Denpasar.

Sudarta, Wayan dan I Putu Dharma. 2013. Laporan Pengabdian Kepada Masyarakat. Memperkuat Subak Anggabaya dari Segi Kelemebagaan. Kerjasama Dinas Kebudayaan Kota Denpasar dengan Program Ekstensi Fakutas pertanian Universitas Udayana. Denpasar.

Sugiyono, 2017. Metode Penelitian Kuantitatif, Kualitatif, dan R\&D. Alfabeta. Bandung.

Suyatna, I Gde. 1982. Ciri-ciri Kedinamisan Kelompok Sosial Tradisional di Bali dan Peranannya dalam Pembangunan. 
Fakultas Pasca Sarjana Institut Pertanian Bogor. Bogor. 